\section{High temperature requirement A1 and fibronectin: two possible players in placental tissue remodelling}

\author{
G. Tossetta, ${ }^{1}$ C. Avellini, ${ }^{1}$ C. Licini, ${ }^{1}$ \\ S.R. Giannubilo, ${ }^{2}$ M. Castellucci, ${ }^{1}$ \\ D. Marzioni ${ }^{1}$
}

1Department of Experimental and Clinical Medicine, Faculty of Medicine,

Polytechnic University of Marche, Ancona

2Department of Clinical Sciences, Faculty

of Medicine, Polytechnic University of

Marche, Ancona, Italy

\begin{abstract}
High temperature requirement Al (HtrAl) is a secreted protease involved in placental development. Fibronectin (FN) is involved in important process such as wound healing, cell adhesion and spreading, growth, migration, and differentiation. The purpose of this study was to analyse the expression patterns of HtrAl in relationship to FN and to the key growth zones of placenta such as mesenchymal villi as well as cell islands and cell columns. We demonstrated that FN and HtrAl are localized in the placental key growth zones suggesting a pivotal role in maintaining the balance among the molecules involved in the placental development and differentiation.
\end{abstract}

\section{Introduction}

High temperature requirement Al (HtrAl) is a secreted protease involved in the degradation of extracellular matrix (ECM) proteins ${ }^{1-3}$ and it is involved in the development of many organs. ${ }^{4}$ In particular, HtrAl was detected during placental development. ${ }^{5-7}$ In addition, HtrA1 has been implicated in placental diseases such as: hydatidiform mole, choriocarcinoma ${ }^{6}$ and preeclampsia. ${ }^{8}$ The altered expression of HtrA1 in these pathologies suggests a possible role of this protein in tissue restructuring and /or remodelling, particularly in the key growth zones of placenta such mesenchymal villi as well as cell islands and cell columns. ${ }^{9,10}$ Placental development and differentiation is also characterized by the presence of fibrinoid. ${ }^{11}$ One fibrinoid component is fibronectin (FN), a 230-270 kD multidomain glycoprotein and an essential component of the ECM. FN is involved in important process such as wound healing, cell adhesion and spreading, growth, migration, and differentiation. ${ }^{12}$ The purpose of this study was to analyse the expression patterns of HtrAl in relationship to FN and to the key growth zones of placenta during the first trimester of gestation.

\section{Materials and Methods}

\section{Tissues}

Placental tissues were obtained from 11 women undergoing voluntary termination of pregnancy at $8(\mathrm{n}=1), 9(\mathrm{n}=3), 10(\mathrm{n}=3), 11$ $(n=2)$ and $12(n=2)$ weeks of gestation (first trimester). Placental samples were fixed overnight in $4 \%$ neutral buffered formalin at $4^{\circ} \mathrm{C}$ then, embedded in paraffin. Pregnant women gave their informed consent to collect placentas and membrane specimens (Division of Obstetrics and Gynaecology, Polytechnic University of Marche). This study was approved by the committee on investigations involving human subjects (Università Politecnica delle Marche, Italy). To the best of our knowledge, there was no pathology affecting placental structure or function. The procedures followed for the collection of samples were in accordance with the Helsinki Declaration of 1975 , as revised in 2000.

\section{Immunohistochemistry}

Immunohistochemical staining was carried out on $4-\mu \mathrm{m}$ thick sections of the paraffinembedded placental tissues as previously described using streptavidin-biotin-peroxidase complex method. ${ }^{8}$ In particular, non-specific antibody binding was blocked with normal goat serum diluted 1:75 for 30 min at room temperature. Afterwards, the sections were incubated overnight at $4{ }^{\circ} \mathrm{C}$ with one of the following primary antibodies diluted in Phosphate Saline Buffer (PBS): a rabbit polyclonal antibody antiHtrAl (Abcam, Cambridge, UK; dilution 1:40); a mouse monoclonal antibody anti-fibronectin (cellular fibronectin, Abcam; dilution 1:50). Pre-treatment by $0.3 \%$ Tween 20 in PBS for 30 min at room temperature was used for HtrAl and no pre-treatment was performed for fibronectin. The following biotinylated secondary antibodies were used at room temperature for $1 \mathrm{~h}$ : for primary polyclonal antibodies a goat anti-rabbit (Vector Laboratories, Burlingame, CA, USA, 1:200 dilution); for the primary monoclonal antibody a goat anti-mouse (Vector Laboratories; 1:200 dilution). Negative controls were performed omitting the first or secondary antibody. Non-immune goat or horse serum or isotype antibodies (rabbit IgG: cat. ab27478, Abcam and mouse IgG1 :cat. ab27479, Abcam) were used in the same way (dilution, volume, incubation conditions) as the respec-
Correspondence: Daniela Marzioni, Department of Experimental and Clinical Medicine, Polytechnic University of Marche, Via Tronto 10/a, 60020 Ancona, Italy.

Tel. +39-071.2206270 - Fax: +39.071 .2206087 .

E-mail: d.marzioni@univpm.it

Key words: Placenta; HtrA1; fibronectin; fibrinoid; mesenchymal villi.

Contributions: GT, study design, acquisition, analysis and interpretation of data, manuscript drafting; DM, study design, acquisition, analysis and interpretation of data, manuscript drafting critical revision and approval; CA, CL, MC, SRG, manuscript critical revision and approval.

Acknowledgments: This study was supported by grants from Università Politecnica delle Marche to D.M., M.C. and PRIN 2010-2011 from Italian Ministry and Research and Instruction (MIUR). Giovanni Tossetta, Caterina Licini and Chiara Avellini are supported by PhD fellowships of Polytechnic University of Marche, Italy.

Conflict of interest: the authors report no conflict of interest.

Received for publication: 13 September 2016. Accepted for publication: 9 Nvember 2016.

This work is licensed under a Creative Commons Attribution-NonCommercial 4.0 International License (CC BY-NC 4.0).

(C) Copyright G. Tossetta et al., 2016

Licensee PAGEPress, Italy

European Journal of Histochemistry 2016; 60:2724 doi:10.4081/ejh.2016.2724

tive primary antibody. The controls were always negative. A semiquantitative system was used to quantify the immunostaining level of HtrAl and FN, (-, no stain; + weak stain; ++ moderate stain; +++ strong stain). Two researchers (DM and GT) independently reviewed all slides in blind. The level of concordance, expressed as the percentage of agreement between the observers was $89 \%$. A concordant decision was taken for the remaining specimens.

\section{Results}

Evaluation of HtrA1 and fibronectin expressions in parallel sections of first trimester placentas

The villous cytotrophoblastic cells (Figure 1a) were regularly positive while the syncytiotrophoblast appeared mainly negative for HtrA1, only few tracts of syncytiotrophoblast were positive. HtrAl immunostaining was par- 
ticularly evident in the stroma of the mesenchymal villi (MV, Figure 1 b,c and Table 1) originated from immature intermediate villus (IIV; Figure $1 \mathrm{a}, \mathrm{b})$. In addition, the most of the placental vessel walls were positive for HtrAl (Figure 1a, Table 1). In addition, HtrA1 immunostaining was present in the villous stroma immediately subjacent to sites of cytotrophoblast cell islands (Figure 1d, Table 1) and cell columns initiation (Figure 1e, Table 1) as well as in the proximal part of extravillous cytotrophoblastic cells of columns and cell islands (Figure 1e, Table 1). These results indicate that HtrAl is expressed in the sites where transitions in cytotrophoblast differentiation take place (initiation sites for column formation). In addition, degenerated villi show a strong immunostaining for HtrAl (Figure 1f, Table 1). A weak and irregular immunostaining was present for FN in the basal lamina of the villous cytotrophoblast while no immunoreactivity of FN was present in the villous trophoblast (villous cytotrophoblast and syncytium, Figure 1h, Table 1). In addition, FN immunostaining was weakly expressed in the stroma of some villi and moderately expressed in the foetal vessel walls (Figure 1h, Table 1). In parallel sections (Figure $1 \mathrm{f}, \mathrm{h}$; Table 1) HtrAl and FN are co-localized in fibrinoid deposits and in the foetal vessels. The distal part of cell columns is strongly marked for FN suggesting a massive production of this protein (Figure 1g; Table 1).

\section{Discussion}

We previously investigated the expression pattern of HtrAl in placental tissue during gestation using a rabbit polyclonal antiserum raised against a purified bacterially expressed glutathione-S-transferase (GST)-HtrA1 (aa363-480) human fusion protein. ${ }^{6,13}$ Using a specific and validated antibody for immunohistochemistry we not only confirmed our previous data ${ }^{6}$ as well as data reported by other authors ${ }^{5,14}$ but we were able to detect new data related to placental development. In particular one of the most important findings is the expression of HtrAl in numerous mesenchymal villi, which are the most primitive villi. ${ }^{10}$ They prevail during the first stage of pregnancy, where they are the forerunners of the other villous types. During later stage of pregnancy, these villi are inconspicuous and act as zones of villous proliferation and further branching. ${ }^{11}$ Interestingly, the first morphological evidence of vasculogenesis can be seen within the cores of mesenchymal villi at 18-20 days post-conception. ${ }^{15,16}$ The presence of HtrAl in the stroma of this type of villi suggests that the resident cells in the stroma such as fibroblasts,
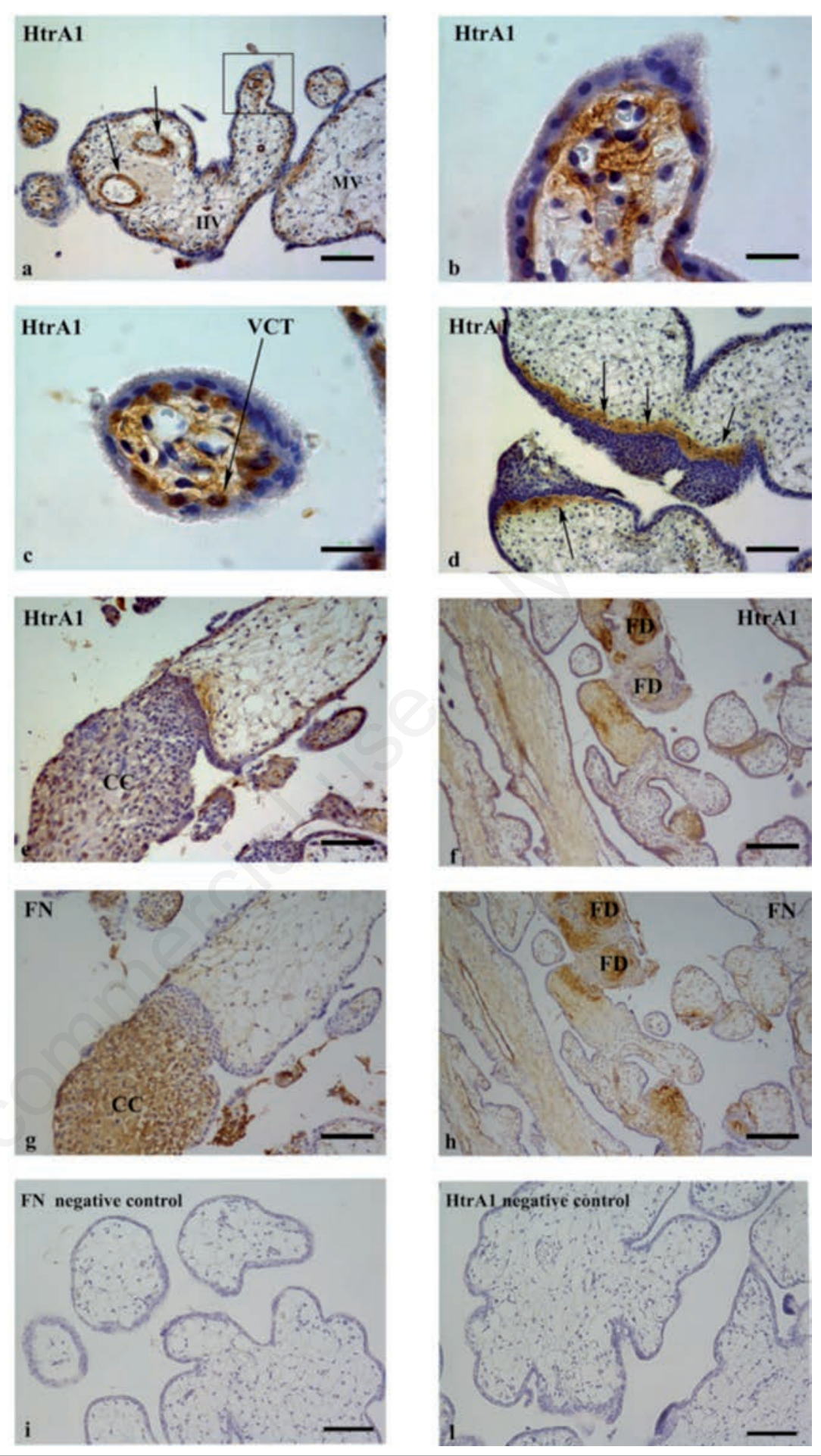

Figure 1. Expression of HtrA1 in first trimester of gestation. a) HtrA1 is expressed in the stroma of Mesenchymal Villous (MV) originated from Immature Intermediated Villous (IIM). The foetal vessel walls are positive for HtrA1 (arrows). b) High magnification of the MV boxed in a). Note the positive staining in the stroma around the foetal capillaries (erythrocytes are visible inside foetal capillaries). c) MV stained for HtrA1, note the strong immunostaining of the villous cytotrophoblast for HtrAl (arrow). d) Cell islands. HtrA1 is strongly expressed in the stroma adjacent to the cell islands (arrows). e) the picture shows a cell column (CC) weakly stained for HtrAl and a more evident immunostaining in the stroma adjacent to the CC showing the same staining depicted in fig. d) for cell islands. f) HtrA1 is strongly expressed in the fibrinoid deposits (FD) and in the foetal vessel walls. g) parallel section to that shown in e) showing FN immunostaining mainly present in the distal part of CC. h) parallel section to that shown in f) showing FN localized in the FD, in the villous stroma and in the foetal vessel walls. i) negative control for FN; l) negative control for HtrA1. Scale bars: a,d,e,f,g,h,i,l) $50 \mu \mathrm{m}$; b,c) $250 \mu \mathrm{m}$. 
Table 1. Semiquantitative evaluation of immunohistochemical analysis.

\begin{tabular}{|c|c|c|c|c|c|c|c|c|c|c|c|c|c|c|}
\hline \multirow[b]{2}{*}{$\begin{array}{l}\text { Placental } \\
\text { samples }\end{array}$} & \multicolumn{2}{|c|}{$\begin{array}{c}\text { Trophoblast } \\
\text { (cytotrophoblast) }\end{array}$} & \multicolumn{2}{|c|}{$\begin{array}{c}\text { Stroma } \\
\text { (mesenchymal } \\
\text { villi) }\end{array}$} & \multicolumn{2}{|c|}{$\begin{array}{l}\text { Stroma } \\
\text { (other villous } \\
\text { types) }\end{array}$} & \multicolumn{2}{|c|}{$\begin{array}{l}\text { Flbrinoid } \\
\text { deposits }\end{array}$} & \multicolumn{2}{|c|}{$\begin{array}{l}\text { Stroma } \\
\text { subjacent to } \\
\text { cell columns/ } \\
\text { islands }\end{array}$} & \multicolumn{2}{|c|}{$\begin{array}{l}\text { Cell columns } \\
\text { or cell } \\
\text { islands }\end{array}$} & \multicolumn{2}{|c|}{$\begin{array}{l}\text { Foetal } \\
\text { vessel } \\
\text { walls }\end{array}$} \\
\hline & HrtAl & FN & HrtA1 & FN & HrtAl & FN & HrtA1 & FN & HrtA1 & FN & HrtA1 & FN & HrtAl & FN \\
\hline 1 & ++ & - & ++ & - & + & + & ++ & ++ & ++ & + & ++ & ++ & +++ & ++ \\
\hline 2 & ++ & - & +++ & + & - & + & ++ & ++ & +++ & + & + & +++ & ++ & ++ \\
\hline 3 & +++ & - & ++ & + & - & + & +++ & ++ & +++ & + & ++ & ++ & +++ & ++ \\
\hline 4 & +++ & - & + & - & - & ++ & +++ & +++ & ++ & + & ++ & +++ & +++ & +++ \\
\hline 5 & +++ & - & ++ & + & - & ++ & +++ & ++ & + & + & + & ++ & ++ & ++ \\
\hline 6 & ++ & + & +++ & + & - & + & ++ & ++ & ++ & + & ++ & ++ & +++ & ++ \\
\hline 7 & +++ & - & ++ & + & + & ++ & +++ & ++ & +++ & ++ & + & +++ & +++ & ++ \\
\hline 8 & +++ & - & ++ & - & - & + & +++ & +++ & ++ & + & ++ & ++ & + & ++ \\
\hline 9 & +++ & - & + & - & + & + & +++ & ++ & +++ & ++ & ++ & +++ & +++ & + \\
\hline 10 & ++ & - & ++ & + & - & ++ & +++ & ++ & ++ & + & + & ++ & + & ++ \\
\hline 11 & ++ & + & +++ & + & - & + & ++ & ++ & + & + & ++ & ++ & ++ & ++ \\
\hline
\end{tabular}

HtrAl, high temperature requirement $\mathrm{Al}$; FN, fibronectin.

macrophages, endothelial cells as well as molecules such as growth factors, ${ }^{17}$ integrins, ${ }^{18}$ laminins ${ }^{19}$ and tenascin ${ }^{20}$ are in close contact with HtrAl and that the ECM molecules can interact with HtrAl. We can hypothesize a possible role of this protease in tissue remodelling during villous sprouting. In addition, other significant data concern the localization of HtrAl in the villous foetal stroma adjacent to cell columns and cell islands. In these latter structures the cytotrophoblastic cells proximally located to the villous stroma are considered as proliferative cells and the presence of this protease in these zones suggests again its involvement in tissue remodelling. The cytotrophoblast columns are sites of extensive modulation of ECM components such as integrin receptors, tenascin, FN..$^{20-22}$ It can be possible that HtrAl facilitates the detachment of villous cytotrophoblastic cells from basal membrane and the consequent cellular migration by its protease activity. We found FN expression at level of the distal part of cell columns where alfa5betal integrin is also expressed, required for cell-fibronectin binding and necessary for cell migration into the uterine wall. ${ }^{21-23}$ In summary, the expression of HtrAl in the stromal sites where transitions in cytotrophoblast differentiation takes place as well as in the proximal part of the cell column, suggests a possible cooperation model of molecules such as FN, tenascin and integrins during placental implantation process. In fact, HtrA1 seems to be important for ECM degradation while FN is important because it provides a support to cell migration. In addition, $\mathrm{FN}$ is a key component involved in fibrosis ${ }^{24}$ and wound healing. ${ }^{25}$ In fact, its production increases considerably in these processes.
Interestingly, we found FN and HtrAl co-localized in fibrinoid deposits suggesting a role for these proteins in villous repair and remodelling. In fact, fibrinoid deposits at the villous surfaces are also due to focal degeneration of trophoblast resulting in a kind of 'villus repair' by a fibrinoid plug that, sometimes, can encase the whole villus. Fibrinoid formation is considered a physiological phenomenon which increases with advancing pregnancy. We can speculate that HtrA1 may play a role in fibrinoid formation that is a process similar to wound healing. If this process is impaired could lead to a massive production of FN causing the degeneration and loss of functionality of the villi as can be observed in pathologic conditions such as preeclampsia. Interestingly, we have previously detected a very weak expression of HtrAl in preeclamptic placenta complicated by intrauterine growth restriction, ${ }^{10}$ thus we can speculate that the absence of HtrAl in these placentas may have a key role in tissue remodelling and in the formation of extensive zones of maldeveloped villi characteristics of this pathology.

\section{References}

1. Canfield AE, Hadfield KD, Rock CF, Wylie EC, Wilkinson FL. HtrA1: a novel regulator of physiological and pathological matrix mineralization? Biochem Soc Trans 2007;35:669-71.

2. Vierkotten S, Muether PS, Fauser S. Overexpression of HTRA1 leads to ultrastructural changes in the elastic layer of
Bruch's membrane via cleavage of extracellular matrix components. PLoS One 2011;6:e22959.

3. Furtwangler T, Chan SC, Bahrenberg G, Richards PJ, Gantenbein-Ritter B. Assessment of the matrix degenerative effects of MMP-3, ADAMTS-4, and HTRA1, injected into a bovine intervertebral disc organ culture model. Spine 2013;38:E137787.

4. De Luca A, De Falco M, De Luca L, Penta R, Shridhar V, Baldi F, et al. Pattern of expression of HtrAl during mouse development. J Histochem Cytochem 2004;52:1609-17.

5. De Luca A, De Falco M, Fedele V, Cobellis L, Mastrogiacomo A, Laforgia V, et al. The serine protease HtrAl is upregulated in the human placenta during pregnancy. $\mathrm{J}$ Histochem Cytochem 2004;52:885-92.

6. Marzioni D, Quaranta A, Lorenzi T, Morroni M, Crescimanno C, De Nictolis M, et al. Expression pattern alterations of the serine protease HtrAl in normal human placental tissues and in gestational trophoblastic diseases. Histol Histopathol 2009;24:1213-22.

7. Marzioni D, Lorenzi T, Altobelli E, Giannubilo SR, Paolinelli F, Tersigni C, et al. Alterations of maternal plasma HTRA1 level in preeclampsia complicated by IUGR. Placenta 2012;33:1036-8.

8. Lorenzi T, Marzioni D, Giannubilo S, Quaranta A, Crescimanno C, De Luca A, et al. Expression patterns of two serine protease HtrAl forms in human placentas complicated by preeclampsia with and without intrauterine growth restriction. Placenta 2009;30:35-40.

9. Castellucci M, Kaufmann P. Evolution of 
the stroma in human chorionic villi throughout pregnancy. Bibl Anat 1982;22:40-45.

10. Castellucci M, Scheper M, Scheffen I, Celona A, Kaufmann P. The development of the human placental villous tree. Anat Embryol (Berl) 1990;181:117-128.

11. Benirschke K, Burton GJ, Baergen RN. Pathology of the human placenta. In: Frank HG, Kaufmann P. editors. Nonvillous parts and trophoblast invasion. Berlin, Springer-Verlag: 2006; p. 226-233.

12. Tian J, Zhang FJ, Lei GH. Role of integrins and their ligands in osteoarthritic cartilage. Rheumatol Int 2015; 35:787-98.

13. Baldi A, De Luca A, Morini M, Battista T, Felsani A, Baldi F, et al. The HtrAl serine protease is down-regulated during human melanoma progression and represses growth of metastatic melanoma cells. Oncogene 2002; 21:6684-88.

14. Nie G, Hale K, Li Y, Manuelpillai U, Wallace EM, Salamonsen LA. Distinct expression and localization of serine protease HtrAl in human endometrium and firsttrimester placenta. Dev Dyn 2002; 235:3448-55.

15. Burton GJ, Charnock-Jones DS, Jauniaux E. Regulation of vascular growth and func- tion in the human placenta. Reproduction 2009;138:895-02.

16. Meraviglia V, Vecellio M, Grasselli A, Baccarin M, Farsetti A, Capogrossi MC, et al. Human chorionic villus mesenchymal stromal cells reveal strong endothelial conversion properties. Differentiation 2012;83:260-70.

17. Muhlhauser J, Marzioni D, Morroni M, Vuckovic M, Crescimanno C, Castellucci M. Codistribution of basic fibroblast growth factor and heparan sulfate proteoglycan in the growth zones of the human placenta. Cell Tissue Res 1996;285:101-7.

18. Snir A, Brenner B, Paz B, Lanir N. Presence of Integrin alpha(IIb)beta 3 in early gestation human trophoblasts: possible involvement of fibrin as a matrix ligand. Thromb Res 2010;12:253-56.

19. Korhonen M, Virtanen I. Immunohistochemical localization of laminin and fibronectin isoforms in human placental villi. J Histochem Cytochem 2001;49:313-22.

20. Castellucci M, Classen-Linke I, Muhlhauser J, Kaufmann P, Zardi L, Chiquet-Ehrismann R. The human placenta: a model for tenascin expression. Histochemistry 1991;95:449-58.

21. Damsky CH, Fitzgerald ML, Fisher SJ.
Distribution patterns of extracellular matrix components and adhesion receptors are intricately modulated during first trimester cytotrophoblast differentiation along the invasive pathway, in vivo. J Clin Invest 1992;89:210-22.

22. Damsky CH, Librach C, Lim KH, Fitzgerald ML, McMaster MT, Janatpour M, et al. Integrin switching regulates normal trophoblast invasion. Development 1994;120: 3657-66.

23. Baczyk, D, Dunk C, Huppertz B, Maxwell C, Reister F, Giannoulias D, et al. Bi-potential behaviour of cytotrophoblasts in first trimester chorionic villi. Placenta 2006;27: 367-74.

24. Francoi D, Venisse L, Marchal-Somme J, Jandrot-Perrus M, Crestani B, Arocas V, et al. Increased expression of protease nexin-1 in fibroblasts during idiopathic pulmonary fibrosis regulates thrombin activity and fibronectin expression. Lab Invest 2014;94:1237-46.

25. Muro AF, Chauhan AK, Gajovic S, Iaconcig A, Porro F, Stanta G, et al. Regulated splicing of the fibronectin EDA exon is essential for proper skin wound healing and normal lifespan. J Cell Biol 2003;162:149-60. 